\title{
Perithyroidal Salivary Gland Acinic Cell Carcinoma: Morphological and Molecular Attributes of a Unique Lesion
}

\author{
C. Christofer Juhlin ${ }^{1,2}$ (1) Sylvia L. Asa ${ }^{3} \cdot K_{\text {Kenbugul Jatta }}{ }^{2} \cdot$ Homeyra Naserhojati Rodsari $^{2} \cdot$ Ivan Shabo $^{4,5}$. \\ Felix Haglund $^{1,2} \cdot$ Brett Delahunt $^{6} \cdot$ Hemamali Samaratunga $^{7} \cdot$ Lars Egevad $^{1,2} \cdot$ Anders Höög $^{1,2}$. Jan Zedenius ${ }^{4,5}$
}

Received: 22 May 2020 / Accepted: 31 May 2020 / Published online: 9 June 2020

(c) The Author(s) 2020

\begin{abstract}
Rarely, salivary gland tumors such as mucoepidermoid carcinoma, mammary analogue secretory carcinoma and mucinous carcinoma arise as primary tumors from ectopic or metaplastic salivary gland tissue adjacent to or within the thyroid gland. We report for the first time a case of primary salivary acinic cell carcinoma (AcCC) adjacent to the thyroid gland in a 71-year-old female patient with Crohns disease and a previous history of malignant melanoma. Following the development of a nodule adjacent to the left thyroid lobe, a fine-needle aspiration biopsy was reported as consistent with a follicular lesion of undetermined significance (Bethesda III). A left-sided hemithyroidectomy was performed. A circumscribed lesion measuring $33 \mathrm{~mm}$ was noted adjacent to the thyroid and trapping parathyroid, it was composed of solid nests and glands with microcystic and follicular patterns. The tumor was negative for thyroid, parathyroid and paraganglioma markers, but positive for pan-cytokeratins, CK7, CD10, CD117, androgen receptor and HNF-beta. A metastasis of a thyroid-like renal cell carcinoma was suspected but ruled out, and the patient had no evident lesions on extensive radiology of the urogenital, pulmonary and GI tracts. Based on the morphology, a diagnosis of AcCC was suggested, and confirmed with DOG1 and PAS-diastase staining. Molecular analyses pinpointed a constitutional ASXL1 variant of uncertain significance, but no fusion events. The patient had no radiological or clinical evidence of parotid, submandibular or sublingual tumors postoperatively, and the excised lesion was therefore assumed to be a primary tumor. We here detail the morphological and immunophenotypic profile of this previously undescribed perithyroidal tumor.
\end{abstract}

Keywords Acinic cell carcinoma $\cdot$ Thyroid $\cdot$ Mutation $\cdot$ Gene fusion

C. Christofer Juhlin

christofer.juhlin@ki.se

1 Department of Oncology-Pathology, Karolinska Institutet, Stockholm, Sweden

2 Department of Pathology and Cytology, Karolinska University Hospital, Stockholm, Sweden

3 University Hospitals Cleveland Medical Center, Case Western Reserve University, Cleveland, Ohio, USA

4 Department of Breast, Endocrine Tumors and Sarcoma, Karolinska University Hospital, Stockholm, Sweden

5 Department of Molecular Medicine and Surgery, Karolinska Institutet, Stockholm, Sweden

6 Department of Pathology and Molecular Medicine, University of Otago, Wellington, New Zealand

7 Department of Molecular and Cellular Pathology, University of Queensland, Brisbane, Australia

\section{Introduction}

Although the bulk of thyroid tumors are derived from the follicular epithelium, a number of unusual lesions from stromal or ectopic tissue components have been reported, including angiosarcoma, parathyroid tumors, paraganglioma, peripheral nerve sheath tumors, solitary fibrous tumors and thymomas, to name a few [1]. Moreover, rare cases of salivary gland tumors have also been described within or adjacent to the thyroid gland, including mucoepidermoid carcinoma, sclerosing mucoepidermoid carcinoma with eosinophilia, mammary analogue secretory carcinoma and mucinous carcinoma [1-7]. These malignant epithelial neoplasms are thought to arise in ectopic salivary gland tissue and are histologically identical to those arising in salivary glands, but often display focal expression of thyroid-related markers such as TTF1, PAX8 and thyroglobulin [1]. From a prognostic perspective, these tumors are often associated 
with poor patient outcome due to the development of regional and distant metastases $[1,8]$.

Acinic cell carcinoma (AcCC) is a low-grade malignant neoplasm that almost exclusively occurs in the major salivary glands, especially the parotid gland, and is usually diagnosed on cytological examination following a fine needle aspiration biopsy (FNAB) [9]. Besides being primarily known as a salivary gland tumor, AcCC also occurs in the pancreas where it derives from pancreatic acinar cells. Salivary-type AcCCs have also been described in the lung, stomach, prostate and breast [9-13]. The tumor is predominantly found in women, and the usual age at diagnosis is $>50$ years $[9,14]$. Previous radiation exposure has been described as a risk factor, and a hereditary link has also been suggested for small subsets of cases $[15,16]$. Although slow growing, AcCCs carry potential for metastatic spread, and long-term follow-up is recommended for most tumors following surgical excision. Histologically, AcCCs usually display a solid, micro-cystic, papillary or follicular growth pattern, and often display immunoreactivity for broad-spectrum keratins, DOG1 and CD117 (c-Kit) [17-22]. Moreover, cytoplasmic droplets of mucin visualized through a Periodic acid-Shiff stain with diastase (PAS-D) have also been described as diagnostic [18, 23].

Given the rarity of AcCC, the underlying genetics driving the development of these tumors have only partly been deciphered. Distinct cytogenetic aberrancies have been described, including deletions covering the short arm of chromosome 6 [24]. Moreover, dysregulation of Rb-mediated growth suppression has also been suggested as a contributing event [25]. To add on this, a recent study observed HTN3-MSANTD3 fusions in a subset of salivary gland AcCCs with an indolent clinical course [26].

In this report, we report a case of AcCC clinically presenting as a thyroid mass, and portray the clinical, histological, immunohistochemical and molecular landscape of this rather unique manifestation.

\section{Case report}

The patient was a 71-year-old female of Swedish ethnicity. She had a medical history of insulin-treated type 2 diabetes, salazopyrine-treated Crohn's disease and pelvospondylitis. She was previously administered infliximab, but this was later changed to rituximab. In 2008, she was diagnosed with a R0 resected amelanotic malignant melanoma of the left forearm, Breslow's depth $3 \mathrm{~mm}$, Clark level IV, with no synchronous metastases. As part of the clinical follow-up procedures, the patient was screened for relapses by various imaging techniques, and in July 2019 , a computerized tomography (CT) of the thorax and abdomen displayed an incidentally discovered $24 \mathrm{~mm}$ nodule that was assumed to be a lymph node adjacent to the caudal aspect of left thyroid lobe (Fig. 1). Shortly afterwards, the patient was referred to our hospital. An ultrasonographyguided fine needle aspiration biopsy (FNAB) of this mass was performed, and the cytology report described hyperplastic follicular thyroid epithelium in groups of varying sizes, consistent with a follicular lesion of undetermined significance (Bethesda III) (Fig. 2). A separate FNAB of the superior aspect of the lobe was consistent with follicular nodular disease. When the patient was seen at the endocrine surgery department, she was clinically and biochemically euthyroid. A decision was made for a diagnostic left-sided hemithyroidectomy, which was performed two weeks later, in which the mass and thyroid lobe were removed en bloc. The operation time was $50 \mathrm{~min}$, and the procedure was complication-free.

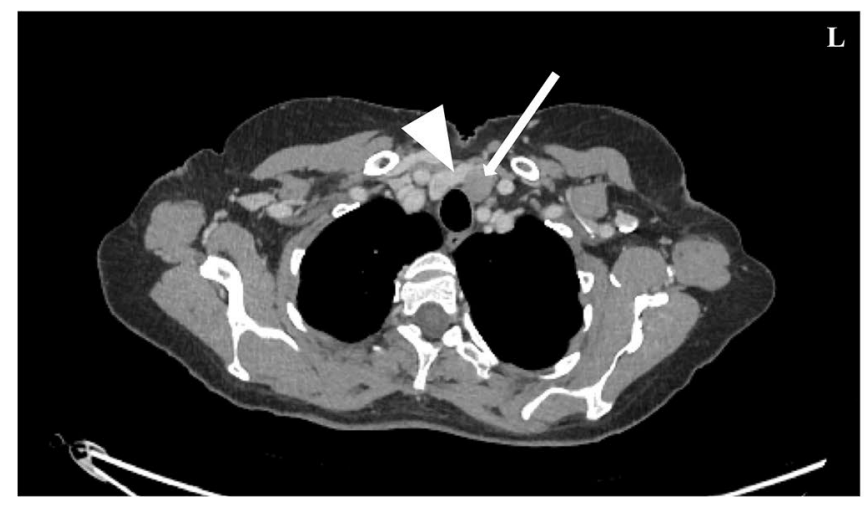

Fig. 1 Preoperative computerized tomography (CT) scan of the superior thoracic inlet. The thyroid gland is marked by a white arrowhead, and the white arrow designates the adjacent $24 \mathrm{~mm}$ lesion originally believed to constitute an enlarged perithyroidal lymph node in level

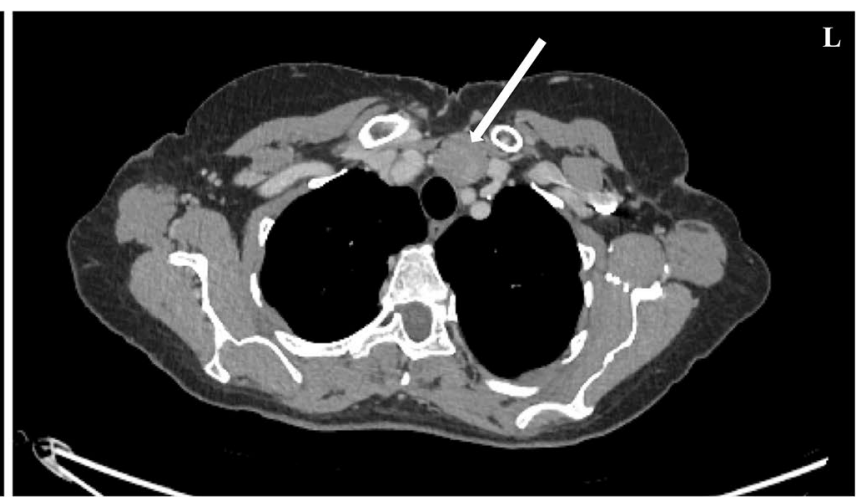

VI. The image on the right is taken caudal to that on the left and highlights the maximum diameter of the mass, reaching the superior thoracic aperture 

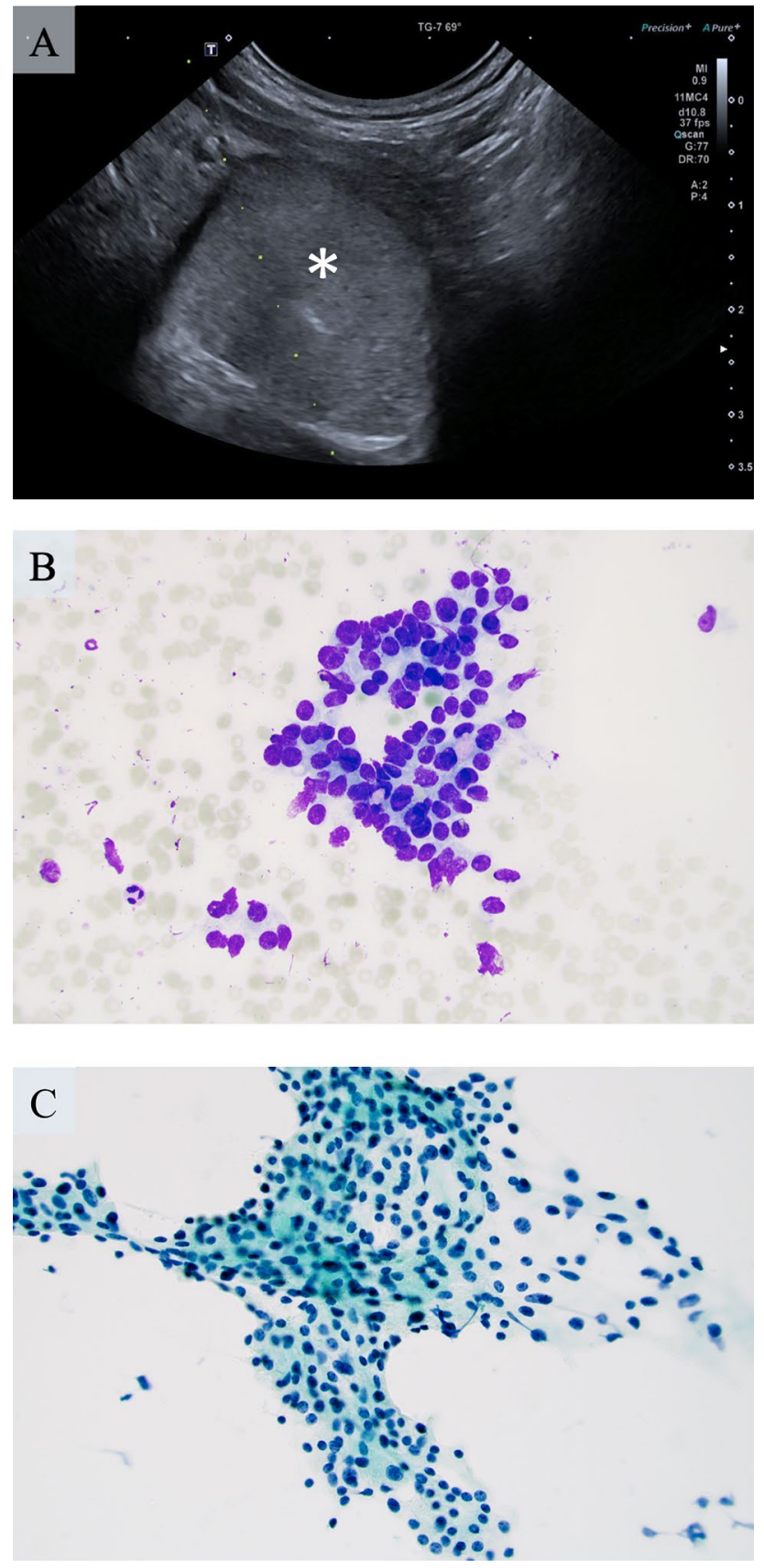

Fig. 2 Ultrasonographic and cytologic hallmarks of the acinic cell carcinoma (AcCC). a Ultrasonography-guided fine-needle aspiration biopsy (FNAB) of the tumor (white asterisk). Note the appearance of the needle tip in the central part of the lesion (directly underneath the asterisk). b May-Grünwald Giemsa (MGG) stain of the aspirated cells at $\times 400$ magnification reveals clusters of tumor cells with round to oval nuclei displaying mild atypia. $\mathbf{c}$ Papanicolaou (PAP) stained smear of the same tumor aspirate

\section{Histopathological Description}

The left thyroid lobe with the adherent mass weighed 18.5 $\mathrm{g}$ and measured $65 \times 30 \times 15 \mathrm{~mm}$. In the caudal aspect of the lobe, firmly attached to the thyroid, there was a well circumscribed tumor that measured $33 \times 33 \times 25 \mathrm{~mm}$ and was macroscopically demarcated from the adjacent thyroid tissue and displayed a pale yellow, homogenous cut surface. The thyroid lobe exhibited a variegated cut surface suggestive of follicular nodular disease with hemorrhage. Microscopically, the well-delineated, partially encapsulated tumor was separate from the adjacent thyroid tissue (Fig. 3). Focally, normal parathyroid tissue was seen at the tumor periphery entrapped in the tumor capsule. The tumor was composed of solid nests and glandular formations with micro-cystic and follicular patterns, and the tumor cells displayed monomorphic nuclei and abundant eosinophilic cytoplasm, which was granulated and vacuolated (Fig. 3). A PAS diastase (PAS-D) stain confirmed the presence of small cytoplasmic PAS-D positive droplets (Fig. 4), which were not evident by routine hematoxylin and eosin (H\&E) staining.

Immunohistochemical analyses (Fig. 4) confirmed the tumor as derived from non-thyroidal tissues, as no immunoreactivity was noted for TTF1, PAX8, thyroglobulin, chromogranin A, calcitonin and CEA. Parathyroid differentiation was also excluded, as the tumor was negative for PTH and GATA3, while retained immunoreactivity was noted within the surrounding parathyroid cells. The tumor stained for pan-cytokeratins (CKMNF) and CK7, but not CK20, and there was focal EMA positivity. Synaptophysin and AFP yielded equivocal immunoreactivity. Negativity was noted for Hepatocyte-specific antigen, CDX2, MUC1, MUC4, CD31, CD56, inhibin alpha and calretinin. A stain for P53 was consistent with wildtype expression. The Ki67 proliferation index was $1.9 \%$.

Given the history of malignant melanoma, stains for this entity were performed, but consistently negative (HMB45, Melan A, SOX10 and S100). Additional markers were ordered, and although the tumor was positive for CD10, CD117, HNF-beta and vimentin, a diagnosis of a thyroidlike follicular carcinoma of the kidney was ruled out based on the overall morphology and a negative PAX8 stain.

The possibility of a salivary gland lesion was then evaluated. The morphology was not that of a mucoepidermoid carcinoma, and the diagnosis of mammary analogue secretory carcinoma was excluded by negative staining for GATA3, mammaglobin, and GCDFP15. However, the tumor was positive for membranous DOG1, consistent with acinic cell differentiation. The tumor was also variably positive for ER, PgR and AR. The immunoprofile thus strongly supported a diagnosis of AcCC.

\section{Postoperative Work-Up}

Clinical investigations, including magnetic resonance tomography (MRI) of the skull base and neck were performed, and tumor masses in any of the large salivary 

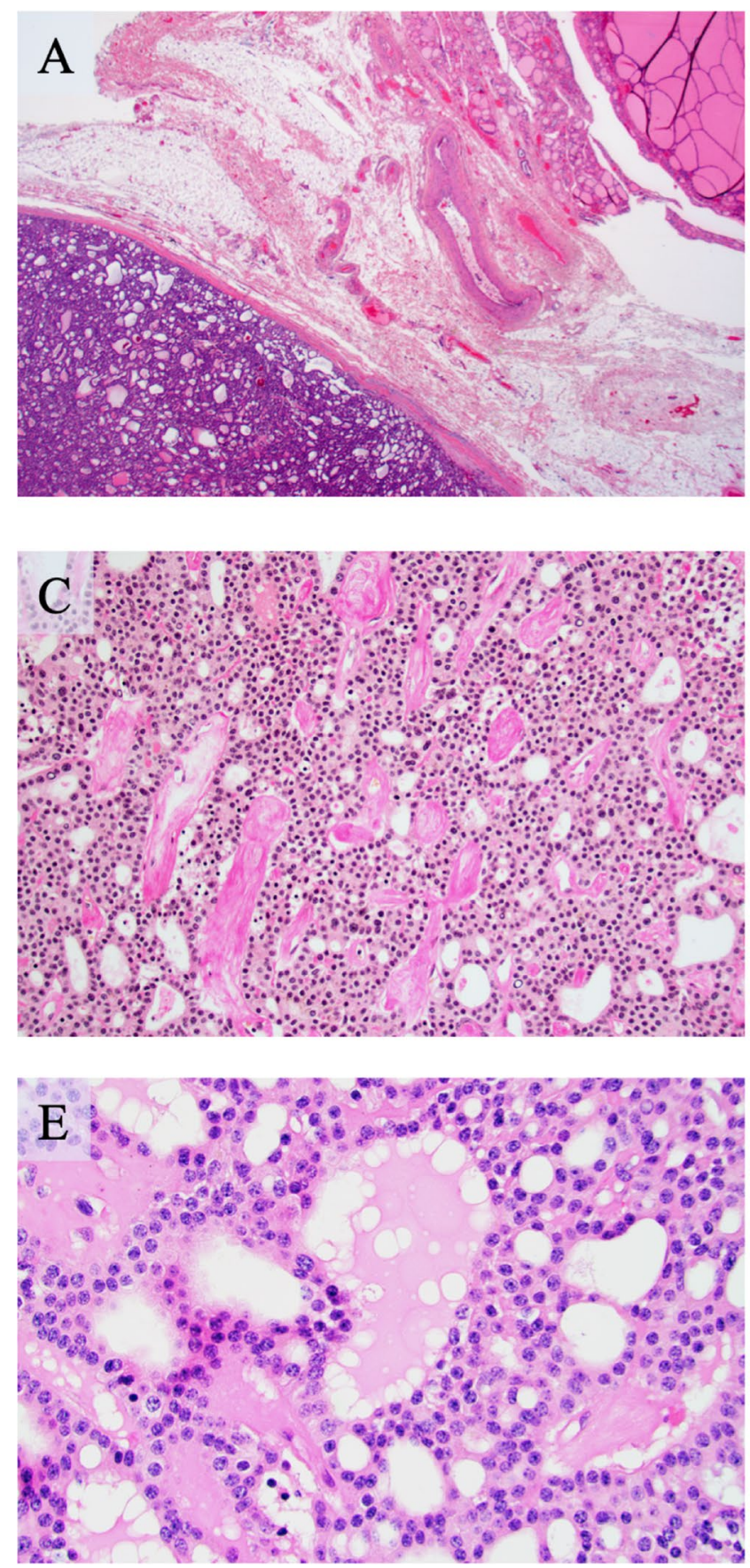

Fig. 3 Histological attributes of the acinic cell carcinoma (AcCC). All photomicrographs represent hematoxylin and eosin (H\&E) stained tissue sections and are magnified $\times 100$ unless otherwise specified. a The AcCC is well delineated and separated from the adjacent thyroid tissue by a fibrous capsule. The thyroid tissue (upper right) displays evidence of follicular nodular disease. There is no evidence of residual ectopic salivary gland tissue in the surrounding tissue. Magnification $\times 20$. b The AcCC is composed of solid nests and glands with microcystic and follicular patterns. The tumor cells are large and polygonal, with abundant pale acidophilic granular and
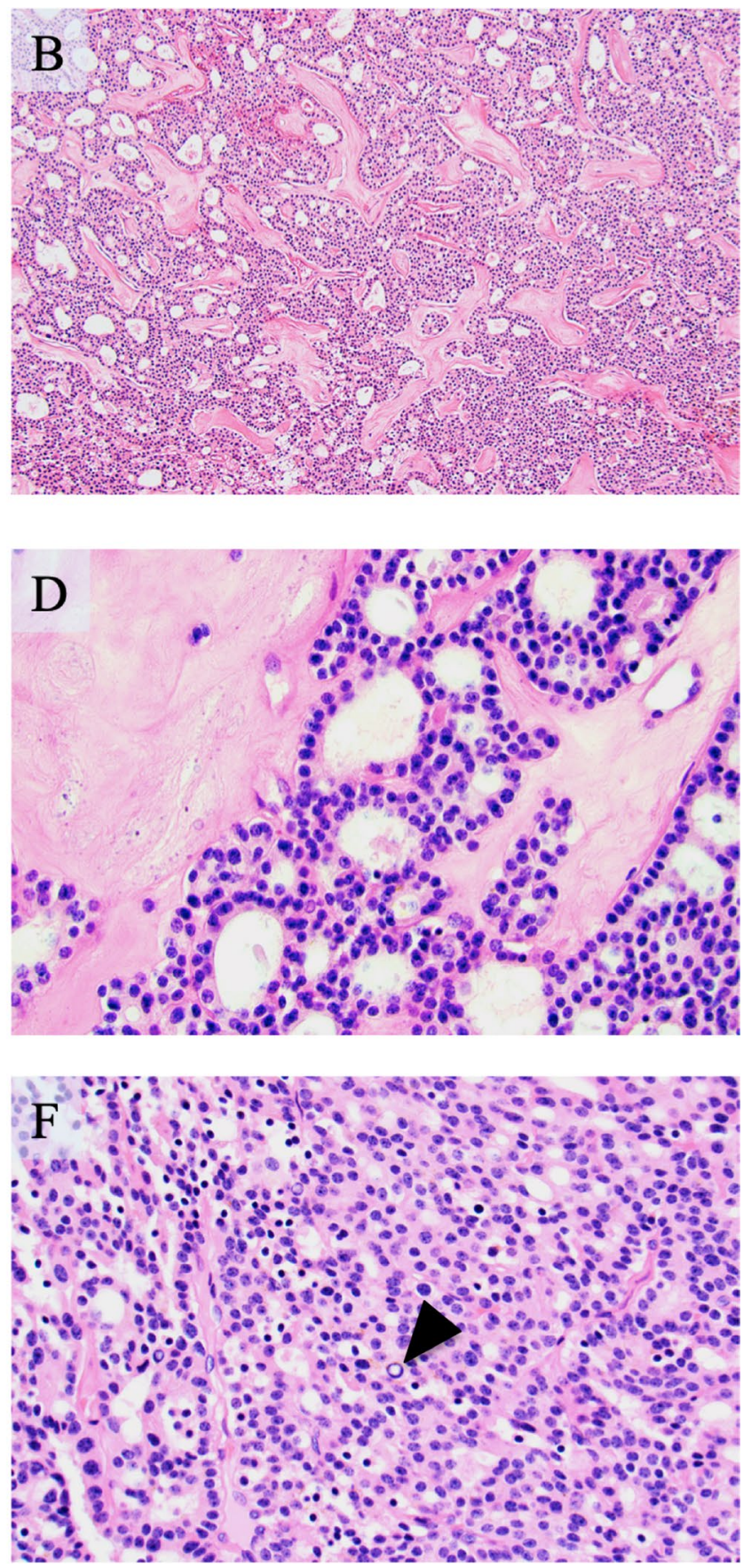

vacuolated cytoplasm. The stroma contains irregular and meandering deposits of collagen-like fibrous tissue. c Van Gieson (VG) stain at magnification $\times 200$ highlighting the fibrous depositions in the surrounding stroma. d High magnification $(\times 400)$ view of the microcystic growth pattern and surrounding amorphous fibrosis. Note the monotonous appearance of the tumor cells. e Area with a microfollicular growth pattern and colloid-like accumulations, mimicking that of a follicular thyroid neoplasm. Magnification $\times 400$. $f$ Solid area, with focal findings of nuclear inclusions (arrowhead). Magnification $\times 400$ 

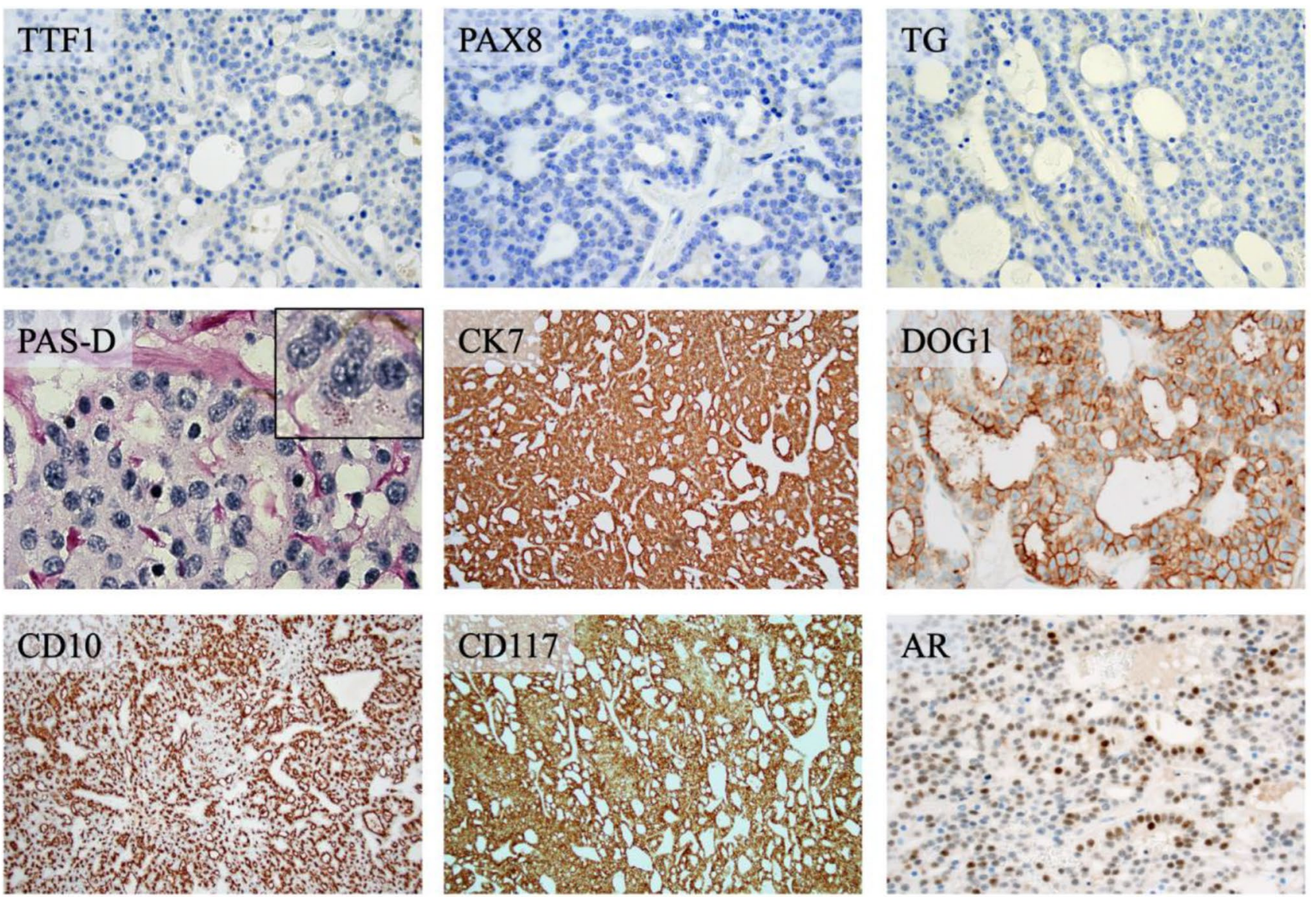

Fig. 4 Histo- and immunohistochemical profile of the acinic cell carcinoma (AcCC). Top row, from left to right: TTF1, PAX8 and thyroglobulin (TG) stains, all unequivocally negative. Middle row, from left to right: PAS diastase (PAS-D) staining displaying intracytoplasmic PAS positive droplets resistant to diastase, thereby verifying them as mucinous. Cytokeratin 7 (CK7) and DOG1 immunoreactiv-

glands (parotid, submandibular or sublingual glands) were excluded. Previous radiological examinations of the abdomen (CT and MRI scans) were also reviewed, without any detectable lesions in the parenchymatous organs except for multiple hepatic hemangiomas as well as bilateral renal cysts. The remaining right thyroid lobe was also investigated by FNAB, and the cytology report indicated no tumors or atypia (Bethesda II). At present, the followup time is 7.5 months, without signs of relapse, but the patient is closely monitored. ity was evident in the overwhelming majority of tumor cells. Bottom row, from left to right: Widespread CD10 and CD117 immunoreactivity, as well as focal androgen receptor (AR) positivity was also evident. Images are magnified $\times 100($ CK7, CD10, CD117), $\times 400$ (TTF1, PAX8, TG, DOG1, AR) and $\times 1000$ (PAS-D)

\section{Focused Next-Generation and Sanger Sequencing of Cancer-Associated Genes}

The Oncomine Solid Tumor Panel (Ion Torrent S5, Hi-Q Chef; Thermo Scientific, MA, USA) was initially used to interrogate tumor DNA extracted from formalin-fixated paraffin-embedded (FFPE) tissue from the primary tumor using next-generation sequencing (NGS). The panel interrogated $>1800$ cancer-associated mutations within $A K T 1$, $A L K, B R A F, C T N N B 1, D D R 2, E G F R, E R B B 2, E R B B 4$, FBXW7, FGFR1, FGFR2, FGFR3, KRAS, NRAS, MAP2K1, MET, NOTCH1, PIK3CA, PTEN, SMAD4, STK11 and TP53. In short, we found no cancer-related mutations using this panel, nor did we find any evidence of a TERT promoter mutation as analyzed by conventional Sanger sequencing. 
The NGS and Sanger sequencing technologies are based on methodology used in clinical routine practice at our pathology department, and the methodology has been previously published [27, 28]. Given the initial negative outcome, an extended mutational and fusion gene screening using the Oncomine Childhood Cancer Panel was performed using DNA and RNA from the tumor respectively. From a mutational perspective, this panel includes comprehensive mutational hotspot coverage of 86 cancer-related genes and full exon coverage of 44 additional genes, thereby interrogating 130 genes in total. By this analysis, a missense single nucleotide variant (SNV) was observed in the Additional sex combs like 1 transcriptional regulator (ASXL1) gene (c.3306G > T, p.E1102D), represented in the Catalogue of Somatic Mutations in Cancer (COSMIC) database as COSM36205 (Table 1). This variant is recurrently reported as a somatic mutation in various hematopoietic disorders such as acute and chronic forms of myeloid leukemia, myelodysplastic syndrome and myelofibrosis, and has also been reported in single carcinomas of the breast and lung [29-37]. By our own in silico analyses using the prediction softwares PolyPhen2 and Mutation Taster 2, the SNV was considered pathogenic (Table 1) [38, 39]. We then ran the same mutational pipeline using DNA from normal thyroid tissue from the same operation and detected the same SNV_-arguing for a probable constitutional variant. However, as the variant is uncommonly reported in public repositories such as The Genome Aggregation Database (GnomAD, minor allele frequency of $<1 \%$ ), we designated this variant as a potential constitutional mutation (Table 1) [40]. True germline mutations in ASXL1 predispose to the Bohring-Opitz syndrome, a condition that most often is congenital and affects an individual's growth development [41]. Our patient exhibits neither family history nor a physical phenotype suggesting this condition. The ASXL1 protein is a member of the Polycomb group of proteins, characterized by transcriptional regulation mediated by ligand-bound nuclear hormone receptors [42]. As loss of ASXL1 expression through mutational inactivation seems to be coupled to a proliferative advantage in functional experiments, $A S X L 1$ is generally considered a tumor suppressor gene [43]. Consulting the Human Protein Atlas (http://www.proteinatlas.org), the $A S X L 1$ gene is ubiquitously expressed across human tissues, including the thyroid and salivary glands [44].

\section{Comprehensive RNA fusion screening}

Salivary gland tumors are commonly driven by specific gene fusion events, not least exemplified by recurrent $M Y B-N F I B$ fusions in adenoid cystic carcinoma, CRTC1-MAML2 fusions in mucoepidermoid carcinoma, EWSR1-ATF 1 fusions in clear cell carcinomas, ETV6-NTRK3 fusions in mammary analogue secretory carcinoma [45-48], as well as the recently described $\mathrm{t}(4 ; 9)(\mathrm{q} 13 ; \mathrm{q} 31)$ translocation that upregulates $N R 4 A 3$ in acinic cell carcinomas $[49,50]$. Therefore, to extend our molecular investigations of this highly unusual tumor type, we employed the Oncomine Childhood Cancer Panel to screen for potential gene fusion events. The assay screens for translocations and fusion events for 97 genes covering more than 1700 fusion isoform variants. After manual inspection of the data, no fusion events in any of the probed genes were detected in the AcCC, and there was no expression of $N R 4 A 3$ mRNA.

\section{Discussion}

In order to derive important clinical knowledge from exceedingly unusual tumor types, the scientific community is largely dependent on case descriptions and small case series in which tumor phenotypes and clinical outcomes are compared. In this report, the main clinical, histological, immunohistochemical and molecular findings of a unique case of a perithyroidal AcCC are summarized. To our knowledge, this specific entity has not previously been described, although single cases of ectopic AcCCs developing as primary tumors of the lateral low-neck area have been reported [51]. Given the novelty, our findings could merit further investigations in institutional series of thyroid-derived follicular-patterned lesions with equivocal histology and aberrant immunohistochemical profiles. Indeed, the AcCC described here displayed morphology partially reminiscent of a follicular

Table 1 Detailed description of the ASXL1 variant discovered by next-generation sequencing

\begin{tabular}{|c|c|c|c|c|c|c|c|c|}
\hline Gene name & $\begin{array}{l}\text { Mutation coor- } \\
\text { dinates }\end{array}$ & $\begin{array}{l}\text { Coding } \\
\text { sequence }\end{array}$ & Protein effect & COSMIC ID & $\begin{array}{l}\text { Number } \\
\text { of mutated } \\
\text { samples in } \\
\text { COSMIC* }\end{array}$ & $\begin{array}{l}\text { PolyPhen2 } \\
\text { prediction }\end{array}$ & $\begin{array}{l}\text { Mutation } \\
\text { Taster } 2 \text { predic- } \\
\text { tion }\end{array}$ & $\begin{array}{l}\text { MAF } \\
\text { (Gno- } \\
\text { mAD) }\end{array}$ \\
\hline$A S X L 1$ & $\begin{array}{l}\mathrm{Chr} \\
\text { 20:32436018 }\end{array}$ & c. $3306 \mathrm{G}>\mathrm{T}$ & p.E1102D & COSM36205 & $\begin{array}{l}\text { Haematopoi- } \\
\text { etic and } \\
\text { lymphoid: } \\
\text { 20, lung: } 3 \text {, } \\
\text { soft tissue: } 1 \text {, } \\
\text { breast: } 1\end{array}$ & $\begin{array}{l}\text { Possibly dam- } \\
\text { aging (0.78) }\end{array}$ & $\begin{array}{l}\text { Disease caus- } \\
\text { ing }\end{array}$ & 0.0095 \\
\hline
\end{tabular}

\footnotetext{
*catalogue of somatic mutations in cancer
} 
thyroid neoplasm, with a focal follicular growth pattern and colloid-like central deposits (Fig. 3). However, the tumor was unequivocally negative for thyroid-associated markers such as TTF1, PAX8 and thyroglobulin (Fig. 4), setting it apart from other thyroid-related salivary gland tumors that are not uncommonly positive for one or several of these proteins.

Most parotid AcCCs are defined by acinar cell differentiation, but several histological growth patterns have been described, including the micro-cystic and follicular patterns observed in our tumor $[17,52]$. Indeed, manifestations of "thyroid-like" appearances have recently been reported in a pancreatic AcCC [53]. Moreover, as the case described here also exhibited PAS-D positive cytoplasmic globules and an immunohistochemical phenotype mirroring that of the parotid tumor counterpart, we are confident that our diagnosis is appropriate. Intriguingly, the $\mathrm{AcCC}$ was surrounded by a thin fibrous capsule with focal depositions of parathyroid tissue, and the possibility of an AcCC metastatic to either the thyroid or parathyroid gland was also considered. However, as clinical and radiological investigations found no signs of a synchronous salivary gland mass, the tumor was therefore assumed to constitute a primary lesion. Whether this AcCC originated from ectopic salivary gland tissue or from metaplasia of a non-related cell type remains obscure, although both of these options have been suggested as plausible explanations for the development of salivary gland tumors arising within or adjacent to the thyroid gland [1].

From a molecular standpoint, we detected a constitutional SNV in the ASXL1 tumor suppressor gene. This SNV is recurrently reported as a somatic mutation in hematological neoplasia, but to our knowledge, this specific variant has never before been reported as a somatic mutation in salivary gland or thyroid tumors. Although not proven on a functional level, one could assume that the ASXL1 constitutional variant found in our patient potentially plays a role in tumor development, given its association to other neoplasia as well as the damaging properties of the missense variant. Indeed, the glutamate to aspartate change at residue 1102 could in theory disrupt the bordering functional domain responsible for interaction with the retinoic acid receptor (RAR) [42]. As the ASXL1 protein normally augments the anti-oncogenic signals mediated by RAR, our mutation could therefore in theory potentially lead to increased proliferation [42]. Although constitutional in nature, the global minor allele frequency of this SNV is reported in around $0.5 \%$, which would argue against a single nucleotide polymorphism (SNP) of limited biological significance. This is also supported by our in silico predictions, suggesting the variant to be impactful. However, the true significance of our findings is yet to be disclosed, and the possibility of this variant being a passenger germline event without clinical consequences must also be considered.
No fusion gene events were detected using a comprehensive clinical panel. Recent findings of $N R 4 A 3$ rearrangements in parotid gland AcCCs have been reported and suggested as a driving genetic event; however, no $N R 4 A 3$ fusions or even expression of $N R 4 A 3 \mathrm{mRNA}$ were detected in our sample [49]. Although the vast majority of parotid AcCCs do express NR4A3 by immunohistochemistry, the lack of $N R 4 A 3 \mathrm{mRNA}$ expression in our case does not directly argue against the diagnosis, as little is known regarding the NR4A3 gene status in non-parotid manifestations of this tumor type [50]. Moreover, given the recent discovery of HTN3-MSANTD3 fusions in subsets of salivary gland AcCCs, it would be interesting to investigate if this genetic aberration was also present in our case [26]. Unfortunately, the gene is not listed among the $>1700$ fusion isoform variants included in our clinical routine panel, and hence no such interrogation could be made. Future investigations using pan-genomic characterization could potentially yield additional insights into the molecular etiology of this exceedingly rare tumor manifestation.

The outcome of our patient is uncertain. When primary in the parotid gland, AcCCs tend to recur locally and spread to regional lymph nodes, lungs and skeleton. In some instances, recurrences might occur some 30 years after original diagnosis, which emphasizes the importance of identifying cases at risk of such late events. Prognostication through conventional histology has proven difficult, but traditional features of malignancy in various tumor types have been reported to be more common in AcCC cases with poor prognosis. Prognostic factors include the occurrence of pleomorphism, frequent mitoses, necrosis and invasive growth patterns, including perineural growth. The tumor described here was histologically indolent, as it was encapsulated and had none of the above-mentioned features, potentially suggesting a more benign clinical course for our patient. Even so, an extensive clinical and radiological follow-up is planned.

\section{Conclusions}

We report the finding of an AcCC adjacent to the thyroid gland, a previously uncharacterized tumor entity exhibiting histological and immunohistochemical features similar to AcCCs arising in salivary glands. As this patient displayed a cancer-associated constitutional mutation in the tumor suppressor $A S X L 1$, this finding could indicate an underlying molecular aberrancy worthy of follow-up studies. Conclusively, we advocate that surgical pathologists worldwide should be aware of this highly unusual differential diagnosis when assessing tumors of the thyroid gland.

Acknowledgements Open access funding provided by Karolinska Institute. The authors acknowledge the valuable input of Dr. Ozgur 
Mete, MD, FRCPC, University Health Network (UHN), Toronto, Canada, for reviewing this case.

Funding The study was financially supported by the Swedish Cancer Society.

Data Availability The data that support the findings of this study are included within the article itself.

\section{Compliance with Ethical Standards}

\section{Conflicts of interest None declared.}

Ethics Approval All procedures performed in studies involving human participants were in accordance with the ethical standards of the institutional and/or national research committee and with the 1964 Helsinki Declaration and its later amendments or comparable ethical standards. Ethical approval was obtained from The Swedish Ethical Review Authority.

Consent to Participate The patient has given her consent to participate in this study.

Consent for Publication The participant has given consent to the submission of the case report to the journal.

Open Access This article is licensed under a Creative Commons Attribution 4.0 International License, which permits use, sharing, adaptation, distribution and reproduction in any medium or format, as long as you give appropriate credit to the original author(s) and the source, provide a link to the Creative Commons licence, and indicate if changes were made. The images or other third party material in this article are included in the article's Creative Commons licence, unless indicated otherwise in a credit line to the material. If material is not included in the article's Creative Commons licence and your intended use is not permitted by statutory regulation or exceeds the permitted use, you will need to obtain permission directly from the copyright holder. To view a copy of this licence, visit http://creativecommons.org/licenses/by/4.0/.

\section{References}

1. Lloyd RV, Osamura RY, Klöppel G, Rosai J, International Agency for Research on Cancer. WHO classification of tumours of endocrine organs. 4th ed. Lyon: International Agency for Research on Cancer; 2017.

2. Franssila KO, Harach HR, Wasenius VM. Mucoepidermoid carcinoma of the thyroid. Histopathology. 1984;8:847-60. https://doi. org/10.1111/j.1365-2559.1984.tb02400.x.

3. Rhatigan RM, Roque JL, Bucher RL. Mucoepidermoid carcinoma of the thyroid gland. Cancer. 1977;39:210-4. https://doi. org/10.1002/1097-0142(197701)39:1<210::aid-cncr282039 0133>3.0.co;2-h.

4. Diaz-Perez R, Quiroz H, Nishiyama RH. Primary mucinous adenocarcinoma of thyroid gland. Cancer. 1976;38:1323-5. https:// doi.org/10.1002/1097-0142(197609)38:3<1323::aid-cncr282038 0335>3.0.co;2-b.

5. Chan JK, Albores-Saavedra J, Battifora H, Carcangiu ML, Rosai J. Sclerosing mucoepidermoid thyroid carcinoma with eosinophilia. A distinctive low-grade malignancy arising from the metaplastic follicles of Hashimoto's thyroiditis. Am J Surg Pathol. 1991;15:438-48.
6. Shah AA, La Fortune K, Miller C, Mills SE, Baloch Z, LiVolsi V, Dacic S, Mahaffey AL, Nikiforova M, Nikiforov YE, Seethala RR. Thyroid sclerosing mucoepidermoid carcinoma with eosinophilia: a clinicopathologic and molecular analysis of a distinct entity. Mod Pathol. 2017;30:329-39. https://doi.org/10.1038/modpa thol.2016.180.

7. Asa SL, Mete O. An unusual salivary gland tumor mimicking papillary thyroid carcinoma: mammary analog secretory carcinoma. Front Endocrinol\&nbsp; 2018;9:555. https://doi. org/10.3389/fendo.2018.00555.

8. Quiroga-Garza G, Lee JH, El-Naggar A, Black JO, Amrikachi M, Zhai QJ, Ayala AG, Ro JY. Sclerosing mucoepidermoid carcinoma with eosinophilia of the thyroid: more aggressive than previously reported. Hum Pathol. 2015;46:725-31. https://doi. org/10.1016/j.humpath.2015.01.012.

9. Al-Zaher N, Obeid A, Al-Salam S, Al-Kayyali BS. Acinic cell carcinoma of the salivary glands: a literature review. Hematol Oncol Stem Cell Ther. 2009;2:259-64. https://doi.org/10.1016/ s1658-3876(09)50035-0.

10. Ripamonti CB, Colombo M, Mondini P, Siranoush M, Peissel B, Bernard L, Radice P, Carcangiu ML. First description of an acinic cell carcinoma of the breast in a BRCA1 mutation carrier: a case report. BMC Cancer. 2013;13:46. https://doi. org/10.1186/1471-2407-13-46.

11. Tanahashi C, Yabuki S, Akamine N, Yatabe Y, Ichihara S. Pure acinic cell carcinoma of the breast in an 80-year-old Japanese woman. Pathol Int. 2007;57:43-6. https://doi.org/10.111 1/j.1440-1827.2007.02055.x.

12. Sun Y, Wasserman PG. Acinar cell carcinoma arising in the stomach: a case report with literature review. Hum Pathol. 2004;35:263-5. https://doi.org/10.1016/j.humpath.2003.09.020.

13. Luebke AM, Schlomm T, Gunawan B, Bonkhoff H, Füzesi L, Erbersdobler A. Simultaneous tumour-like, atypical basal cell hyperplasia and acinar adenocarcinoma of the prostate: a comparative morphological and genetic approach. Virchows Arch. 2005;446:338-41. https://doi.org/10.1007/s00428-004-1199-6.

14. Hoffman HT, Karnell LH, Robinson RA, Pinkston JA, Menck HR. National Cancer Data Base report on cancer of the head and neck: acinic cell carcinoma. Head Neck. 1999;21:297309. https://doi.org/10.1002/(sici)1097-0347(19990 7) $21: 4<297$ ::aid-hed2>3.0.co;2-r.

15. Delides A, Velegrakis G, Kontogeorgos G, Karagianni E, Nakas D, Helidonis E. Familial bilateral acinic cell carcinoma of the parotid synchronous with pituitary adenoma: case report. Head Neck. 2005;27:825-8. https://doi.org/10.1002/hed.20219.

16. Squires JE, Mills SE, Cooper PH, Innes DJ, McLean WC. Acinic cell carcinoma: its occurrence in the laryngotracheal junction after thyroid radiation. Arch Pathol Lab Med. 1981;105:266-8.

17. Thompson LDR, Wenig BM, Müller S, Nelson B. Diagnostic pathology: head \& neck. 2nd ed. Philadelphia, PA: Elsevier; 2016.

18. Chênevert J, Duvvuri U, Chiosea S, Dacic S, Cieply K, Kim J, Shiwarski D, Seethala RR. DOG1: a novel marker of salivary acinar and intercalated duct differentiation. Mod Pathol. 2012;25:919-29. https://doi.org/10.1038/modpathol.2012.57.

19. Abd Raboh NM, Hakim SA. Diagnostic role of DOG1 and p63 immunohistochemistry in salivary gland carcinomas. Int J Clin Exp Pathol. 2015;8:9214-22.

20. Hemminger J, Iwenofu OH. Discovered on gastrointestinal stromal tumours 1 (DOG1) expression in non-gastrointestinal stromal tumour (GIST) neoplasms. Histopathology. 2012;61:170-7. https ://doi.org/10.1111/j.1365-2559.2011.04150.x.

21. Andreadis D, Epivatianos A, Poulopoulos A, Nomikos A, Papazoglou G, Antoniades D, Barbatis C. Detection of C-KIT (CD117) molecule in benign and malignant salivary gland tumours. Oral 
Oncol. 2006;42:57-65. https://doi.org/10.1016/j.oraloncolo gy.2005.06.014.

22. Skálová A, Sima R, Vanecek T, Muller S, Korabecna M, Nemcova J, Elmberger G, Leivo I, Passador-Santos F, Walter J, Rousarova M, Jedlickova K, Curik R, Geierova M, Michal M. Acinic cell carcinoma with high-grade transformation: a report of 9 cases with immunohistochemical study and analysis of TP53 and HER-2/ neu genes. Am J Surg Pathol. 2009;33:1137-45. https://doi. org/10.1097/PAS.0b013e3181a38e1c.

23. Panicker N, Jariwala P, Buch A, Joshi M. The utility of periodic acid schiff with diastase and alcian blue stains on fine needle aspirates of breast and salivary gland neoplasms. J Cytol. 2012;29:221-5. https://doi.org/10.4103/0970-9371.103938.

24. el-Naggar AK, Abdul-Karim FW, Hurr K, Callender D, Luna MA, Batsakis JG. Genetic alterations in acinic cell carcinoma of the parotid gland determined by microsatellite analysis. Cancer Genet Cytogenet. 1998;102:19-24. https://doi.org/10.1016/ s0165-4608(97)00273-2.

25. Liu T, Zhu E, Wang L, Okada T, Yamaguchi A, Okada N. Abnormal expression of $\mathrm{Rb}$ pathway-related proteins in salivary gland acinic cell carcinoma. Hum Pathol. 2005;36:962-70. https ://doi.org/10.1016/j.humpath.2005.06.014.

26. Andreasen S, Varma S, Barasch N, Thompson LDR, Miettinen M, Rooper L, Stelow EB, Agander TK, Seethala RR, Chiosea SI, Homøe P, Wessel I, Larsen SR, Erentaite D, Bishop JA, Ulhøi BP, Kiss K, Melchior LC, Pollack JR, West RB. The HTN3MSANTD3 fusion gene defines a subset of acinic cell carcinoma of the salivary gland. Am J Surg Pathol. 2019;43:489-96. https ://doi.org/10.1097/PAS.0000000000001200.

27. Hysek M, Paulsson JO, Jatta K, Shabo I, Stenman A, Höög A, Larsson C, Zedenius J, Juhlin CC. Clinical routine TERT promoter mutational screening of follicular thyroid tumors of uncertain malignant potential (FT-UMPs): a useful predictor of metastatic disease. Cancers. 2019. https://doi.org/10.3390/cance rs11101443

28. Hysek M, Jatta K, Stenman A, Darai-Ramqvist E, Zedenius J, Höög A, Juhlin CC. Signet ring cell variant of follicular thyroid carcinoma: report of two cases with focus on morphological, expressional and genetic characteristics. Diagn Pathol. 2019;14:127. https://doi.org/10.1186/s13000-019-0904-3.

29. Carbuccia N, Trouplin V, Gelsi-Boyer V, Murati A, Rocquain J, Adélaïde J, Olschwang S, Xerri L, Vey N, Chaffanet M, Birnbaum D, Mozziconacci MJ. Mutual exclusion of ASXL1 and NPM1 mutations in a series of acute myeloid leukemias. Leukemia. 2010;24:469-73. https://doi.org/10.1038/leu.2009.218.

30. Makishima H, Jankowska AM, McDevitt MA, O'Keefe C, Dujardin S, Cazzolli H, Przychodzen B, Prince C, Nicoll J, Siddaiah H, Shaik M, Szpurka H, Hsi E, Advani A, Paquette R, Maciejewski JP. CBL, CBLB, TET2, ASXL1, and IDH1/2 mutations and additional chromosomal aberrations constitute molecular events in chronic myelogenous leukemia. Blood. 2011;117:e198-206. https://doi.org/10.1182/blood-2010-06292433.

31. Ohgami RS, Ma L, Merker JD, Gotlib JR, Schrijver I, Zehnder JL, Arber DA. Next-generation sequencing of acute myeloid leukemia identifies the significance of TP53, U2AF1, ASXL1, and TET2 mutations. Mod Pathol. 2015;28:706-14. https://doi.org/10.1038/ modpathol.2014.160.

32. Patnaik MM, Padron E, LaBorde RR, Lasho TL, Finke CM, Hanson CA, Hodnefield JM, Knudson RA, Ketterling RP, Al-kali A, Pardanani A, Ali NA, Komrokji RS, Komroji RS, Tefferi A. Mayo prognostic model for WHO-defined chronic myelomonocytic leukemia: ASXL1 and spliceosome component mutations and outcomes. Leukemia. 2013;27:1504-10. https://doi.org/10.1038/ leu. 2013.88 .
33. Stein BL, Williams DM, O'Keefe C, Rogers O, Ingersoll RG, Spivak JL, Verma A, Maciejewski JP, McDevitt MA, Moliterno AR. Disruption of the ASXL1 gene is frequent in primary, postessential thrombocytosis and post-polycythemia vera myelofibrosis, but not essential thrombocytosis or polycythemia vera: analysis of molecular genetics and clinical phenotypes. Haematologica. 2011;96:1462-9. https://doi.org/10.3324/haematol.2011.045591.

34. Szpurka H, Jankowska AM, Makishima H, Bodo J, Bejanyan N, Hsi ED, Sekeres MA, Maciejewski JP. Spectrum of mutations in RARS-T patients includes TET2 and ASXL1 mutations. Leuk Res. 2010;34:969-73. https://doi.org/10.1016/j.leukr es.2010.02.033.

35. Thol F, Friesen I, Damm F, Yun H, Weissinger EM, Krauter J, Wagner K, Chaturvedi A, Sharma A, Wichmann M, Göhring G, Schumann C, Bug G, Ottmann O, Hofmann W-K, Schlegelberger B, Heuser M, Ganser A. Prognostic significance of ASXL1 mutations in patients with myelodysplastic syndromes. J Clin Oncol. 2011;29:2499-506. https://doi.org/10.1200/JCO.2010.33.4938.

36. Cornen S, Guille A, Adélaïde J, Addou-Klouche L, Finetti P, Saade M-R, Manai M, Carbuccia N, Bekhouche I, Letessier A, Raynaud S, Charafe-Jauffret E, Jacquemier J, Spicuglia S, de The H, Viens P, Bertucci F, Birnbaum D, Chaffanet M. Candidate luminal $\mathrm{B}$ breast cancer genes identified by genome, gene expression and DNA methylation profiling. PLoS ONE. 2014;9:e81843. https://doi.org/10.1371/journal.pone.0081843.

37. McMillan EA, Ryu M-J, Diep CH, Mendiratta S, Clemenceau JR, Vaden RM, Kim J-H, Motoyaji T, Covington KR, Peyton M, Huffman K, Wu X, Girard L, Sung Y, Chen P-H, Mallipeddi PL, Lee JY, Hanson J, Voruganti S, Yu Y, Park S, Sudderth J, DeSevo C, Muzny DM, Doddapaneni H, Gazdar A, Gibbs RA, Hwang T-H, Heymach JV, Wistuba I, Coombes KR, Williams NS, Wheeler DA, MacMillan JB, Deberardinis RJ, Roth MG, Posner BA, Minna JD, Kim HS, White MA. Chemistry-first approach for nomination of personalized treatment in lung cancer. Cell. 2018;173:864-78.e29. https://doi.org/10.1016/j.cell.2018.03.028.

38. Schwarz JM, Cooper DN, Schuelke M, Seelow D. MutationTaster2: mutation prediction for the deep-sequencing age. Nat Methods. 2014;11:361-2. https://doi.org/10.1038/nmeth.2890.

39. Adzhubei IA, Schmidt S, Peshkin L, Ramensky VE, Gerasimova A, Bork P, Kondrashov AS, Sunyaev SR. A method and server for predicting damaging missense mutations. Nat Methods. 2010;7:248-9. https://doi.org/10.1038/nmeth0410-248.

40. Karczewski KJ, Francioli LC, Tiao G, Cummings BB, Alföldi J, Wang Q, Collins RL, Laricchia KM, Ganna A, Birnbaum DP, Gauthier LD, Brand H, Solomonson M, Watts NA, Rhodes D, Singer-Berk M, Seaby EG, Kosmicki JA, Walters RK, Tashman K, Farjoun Y, Banks E, Poterba T, Wang A, Seed C, Whiffin N, Chong JX, Samocha KE, Pierce-Hoffman E, Zappala Z, O'Donnell-Luria AH, Minikel EV, Weisburd B, Lek M, Ware JS, Vittal C, Armean IM, Bergelson L, Cibulskis K, Connolly KM, Covarrubias M, Donnelly S, Ferriera S, Gabriel S, Gentry J, Gupta N, Jeandet T, Kaplan D, Llanwarne C, Munshi R, Novod S, Petrillo N, Roazen D, Ruano-Rubio V, Saltzman A, Schleicher M, Soto J, Tibbetts K, Tolonen C, Wade G, Talkowski ME, The Genome Aggregation Database Consortium, Neale BM, Daly MJ, MacArthur DG (2019) Variation across 141,456 human exomes and genomes reveals the spectrum of loss-of-function intolerance across human protein-coding genes. Genomics. BioRxIv Preprint.

41. Hoischen A, van Bon BWM, Rodríguez-Santiago B, Gilissen C, Vissers LELM, de Vries P, Janssen I, van Lier B, Hastings R, Smithson SF, Newbury-Ecob R, Kjaergaard S, Goodship J, McGowan R, Bartholdi D, Rauch A, Peippo M, Cobben JM, Wieczorek D, Gillessen-Kaesbach G, Veltman JA, Brunner HG, de Vries BBBA. De novo nonsense mutations in ASXL1 cause Bohring-Opitz syndrome. Nat Genet. 2011;43:729-31. https://doi. org/10.1038/ng.868. 
42. Cho Y-S, Kim E-J, Park U-H, Sin H-S, Um S-J. Additional sex comb-like 1 (ASXL1), in cooperation with SRC-1, acts as a ligand-dependent coactivator for retinoic acid receptor. J Biol Chem. 2006;281:17588-98. https://doi.org/10.1074/jbc.M5126 16200.

43. Wu X, Bekker-Jensen IH, Christensen J, Rasmussen KD, Sidoli S, Qi Y, Kong Y, Wang X, Cui Y, Xiao Z, Xu G, Williams K, Rappsilber J, Sønderby CK, Winther O, Jensen ON, Helin K. Tumor suppressor ASXL1 is essential for the activation of INK4B expression in response to oncogene activity and anti-proliferative signals. Cell Res. 2015;25:1205-18. https://doi.org/10.1038/ cr.2015.121.

44. Uhlen M, Zhang C, Lee S, Sjöstedt E, Fagerberg L, Bidkhori G, Benfeitas R, Arif M, Liu Z, Edfors F, Sanli K, von Feilitzen K, Oksvold P, Lundberg E, Hober S, Nilsson P, Mattsson J, Schwenk JM, Brunnström H, Glimelius B, Sjöblom T, Edqvist P-H, Djureinovic D, Micke P, Lindskog C, Mardinoglu A, Ponten F. A pathology atlas of the human cancer transcriptome. Science. 2017. https://doi.org/10.1126/science.aan2507.

45. Persson M, Andrén Y, Mark J, Horlings HM, Persson F, Stenman G. Recurrent fusion of MYB and NFIB transcription factor genes in carcinomas of the breast and head and neck. Proc Natl Acad Sci USA. 2009;106:18740-4. https://doi.org/10.1073/pnas.09091 14106.

46. Tirado Y, Williams MD, Hanna EY, Kaye FJ, Batsakis JG, ElNaggar AK. CRTC1/MAML2 fusion transcript in high grade mucoepidermoid carcinomas of salivary and thyroid glands and Warthin's tumors: implications for histogenesis and biologic behavior. Genes Chromosomes Cancer. 2007;46:708-15. https:// doi.org/10.1002/gcc. 20458.

47. Skálová A, Vanecek T, Sima R, Laco J, Weinreb I, Perez-Ordonez B, Starek I, Geierova M, Simpson RHW, Passador-Santos F, Ryska A, Leivo I, Kinkor Z, Michal M. Mammary analogue secretory carcinoma of salivary glands, containing the ETV6-NTRK3 fusion gene: a hitherto undescribed salivary gland tumor entity. Am J Surg Pathol. 2010;34:599-608. https://doi.org/10.1097/ PAS.0b013e3181d9efcc.
48. Antonescu CR, Katabi N, Zhang L, Sung YS, Seethala RR, Jordan RC, Perez-Ordoñez B, Have C, Asa SL, Leong IT, Bradley G, Klieb H, Weinreb I. EWSR1-ATF1 fusion is a novel and consistent finding in hyalinizing clear-cell carcinoma of salivary gland. Genes Chromosomes Cancer. 2011;50:559-70. https://doi. org/10.1002/gcc.20881.

49. Haller F, Bieg M, Will R, Körner C, Weichenhan D, Bott A, Ishaque N, Lutsik P, Moskalev EA, Mueller SK, Bähr M, Woerner A, Kaiser B, Scherl C, Haderlein M, Kleinheinz K, Fietkau R, Iro H, Eils R, Hartmann A, Plass C, Wiemann S, Agaimy A. Enhancer hijacking activates oncogenic transcription factor NR4A3 in acinic cell carcinomas of the salivary glands. Nat Commun. 2019;10:368. https://doi.org/10.1038/s41467-018-08069-x.

50. Haller F, Skálová A, Ihrler S, Märkl B, Bieg M, Moskalev EA, Erber R, Blank S, Winkelmann C, Hebele S, Baněčková M, Wiemann S, Müller S, Zenk J, Eils R, Iro H, Hartmann A, Agaimy A. Nuclear NR4A3 immunostaining is a specific and sensitive novel marker for acinic cell carcinoma of the salivary glands. Am J Surg Pathol. 2019;43:1264-72. https://doi.org/10.1097/PAS.00000 00000001279.

51. Perzin KH, Livolsi VA. Acinic cell carcinoma arising in ectopic salivary gland tissue. Cancer. 1980;45:967-72. https://doi. org/10.1002/1097-0142(19800301)45:5<967::aid-cncr282045 0522>3.0.co;2-a.

52. Batsakis JG, Luna MA, el-Naggar AK. Histopathologic grading of salivary gland neoplasms: II. Acinic cell carcinomas. Ann Otol Rhinol Laryngol. 1990;99:929-33. https://doi.org/10.1177/00034 8949009901115.

53. Saglietti C, Schneider V, Bongiovanni M, Missiaglia E, Bisig B, Dorta G, Demartines N, Sempoux C, La Rosa S. Acinar cell carcinoma of the pancreas with thyroid-like follicular features: first description of a new diagnostic challenging subtype. Virchows Arch. 2019;475:789-94. https://doi.org/10.1007/s00428-01902628-3. 